\title{
The Maxim of Truth in Political Interviews
}

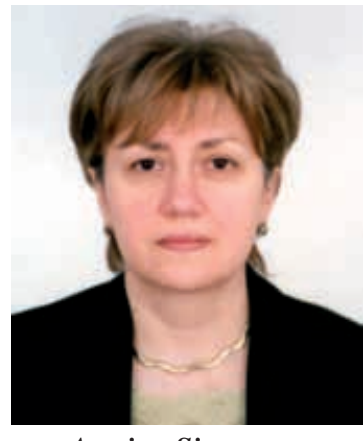

Armine Simonyan

$\mathrm{F}^{\text {or }}$ centuries language and politics have been

$\mathrm{F}_{\text {permanently interwoven. This interaction reveals not }}$ only politics itself but the capacity of human language.

Politics is mainly viewed as a struggle for power. This approach deals with the

political institutions of the state canonized in the Constitution, civil and legal codes, state institutions and parties, the speeches of professional politicians, interest groups, etc.

According to P. Chilton, politics is a means of cooperation within different layers of a society for determining clashes of interest over money and influence, which presupposes conflicts of dominance between individuals, genders, social groups of various kinds (Chilton 2004).

In totalitarian countries, a political system is implemented exclusively by violence and force. In contrast, politics in a democratic nation demands persuasion, truth and civil morality bound by the paramount grip of language. Politics is thus predominantly the use of language. Only in and through language can one issue commands and threats, ask questions, and make offers and promises. Only language can provide a political institution with an outlet to declare war, claim innocence or guilt in court, and raise or lower taxes.

The use of language can also create an institution. For example, swearing an oath is a specific institution which presupposes special legal training carried out by a professional lawyer. Swearing an oath is at the same time an act of speech.

Speech Act Theory and Pragmatics have adopted a completely different approach to the language of politicians, revealing the discrepancy between what is said and what is meant. "In the European and American cultural contexts, politicians are generally expected to act better and thus be better than ordinary people. They are expected to be faultless, perfect citizens, who not only preach but also practice what they preach. In other words, the private and public domains of politicians are expected to be coherent. Unfortunately, very often in politics a speaker may say something but actually mean something else" (Fetzer 2002). Politicians are said to employ numerous indirect speech acts in order to remain diplomatically unclear about controversial issues. The differentiation between direct and indirect communicative intention in politics is quite relevant within the sphere of political interview.

What do the following communicative situations have in common - an ordinary, mundane, face-to-face conversation and a special type of interaction known as a political interview? 
Ideal verbal communication means self-interested, reciprocal interaction which presupposes the fundamental expectation that both sides should communicate truthfully and sincerely. Serious analysis on this problem was carried out by the famous philosopher and linguist Paul Grice. According to Grice's conception, human communication cannot exist without a cooperative principle which involves 4 types of maxims:

I. Maxim of Quantity. Make your contribution as informative as is required. Do nol make your contribution more informative than is required.

11. Maxim of Quality. Supermaxim: Try to make your contribution one that is true. Specific maxims: Do not say what you believe to be false. Do not say that for which you lack adequate evidence.

1II. Maxim of Relation. Be relevant.

IV. Maxim of Manner. Supennaxim: Be perspicuous. Specific maxims: Avoid obscurity of expression. Avoid ambiguity. Be brief. Be orderiy.

P. Grice's conversational maxims can be interpreted as a special way of conducting rational interaction where particular kinds of talk-exchange are defined by these specific maxims. Another way to interpret maxins is to treat of them as social arrangements of various norms (Grice 1975). Abandoning the maxims would suggest refusing to communicate properly altogether. However, violations of maxims are also possible. One could violate the maxins by refusing to give information in court or telling a half-truth and calculating that nobody would find out.

On the whole, P. Grice's maxims may be better understood as guidelines for successful communication. If the speaker happens to be a politician and tries to comply with the cooperative principle, we still lend to look for other meanings that could be by the sentence.

Margaret Thatcher has established her own distinguished influence in the history of 20 th century politics. Thatcher came to power in a time when the United Kingdom was facing a long period of economic and political stagnation. Her policy, which would later be identified as Thatcherism, involved reduced governmental spending and broad privatization of the governmental sector. Her severe and harsh measures provoked a storm of public prolest. However, Margaret Thatcher stood firm in supporting her economic policy. Margaret Thatcher's language was striking and extremely colorful, with constant interplay and subtle interaction between the linguistic units and their desirable effects on the audience. The peculiarities of Margaret Thatcher's way of speaking created a unique style, which in the course of time proved to be a major contribution to expanding the boundaries of such a phenomenon as political interview.

As we know, pragmatics is concerned with bridging the explanatory gap between sentence meaning and the speaker's meaning. Context in the case of political interview must be interpreted as situation, as it may include any imaginable extralinguistic factor including social, environmental, and psychological manipulation. The concept of truth should be evaluated in political interviews through the situation anchored by the frames of objective, social and subjective worlds (Fetzer 2002).

The world of objective truth corresponds or equals to the same factual knowledge which exists or is known in any field of politics. While expressing the objective truth, a politician completely lacks personal evaluation. 
Social truth is designated for framing people's political ideas and concepts. Social truth is to be appropriate, relevant and should reflect the major political trends of the country. Politicians tend to evaluate social truth by regarding the rights and obligations of each citizen.

The world of subjective truth is not so much appreciated by any politician. This is the hidden world which is to be kept aside.

A political interview as an entity of objective. subjective and social worlds is the result of several interactions. There is interaction between the $I R$ and $I E$, interaction between IR and the audience, and the interaction between IE and the audience. The interviewer should formulate his questions in such a way so that the interviewee feels at ease to answer them.

Let us observe how the maxim of quality or truth is realized in the political interview with Margaret Thatcher. On Sunday, Jume 29, 1992 CNN reporter Bernard Shaw addressed the Prime Minister of Great Britain. The interview was structured by a question and answer format. It began like this.

Shaw: Lady, Thatcher, from America to India, to Jamaica, poims in between and. now, Hong Kong. Your thoughts on losing another British colony?

At the beginning of the interview, the interviewer implements an introductory segno involving ideas which are sure to be known by the audience. The preface is then followed by an explicit interrogative portion (Your thoughts on losing another British colony?) which demands a straightforward reply from Margaret Thatcher. Her answer is:

Thatcher: Particularly sad, the circumstances are unique, all the other things that vou mentioned ... we did rule over for a time and brought each to independence, because we were able to do that.

The word-combination particularly sad linguistically expressed by the combination 'adverb plus adjective', reveals Thatcher's personal evaluation of the problem. But this estimation does not solely portray her attitude; it also reflects the feelings of the nation as a whole. The fall of the British Empire was and has been a serious blow to Britain's continued economic domination in the world.

Here we witness explicit linking of the subjective and the objective field of truth evaluation.

In the next sentence Margaret Thatcher uses the emphatic construction we did ruie followed by the word of apparent positive evaluation independence, and afterwards comes the modal expression we were able to do that. The author, addressing the audience, re-establishes the values which should be known and appreciated by the nation. This is the sphere of social tiuth. According to Margaret Thatcher, a prominent politician, British people must focus their attention primarily on the fact that Great Britain brought these nations to independence implementing democracy and parliamentary system. This was the answer to the first part of the question, in which she managed to combine different aspects of the concept of truth. Meanwhile, she demonstrated the ability of preserving the phenomenon of neutrality. The maintenance of formal neutralism based on the interaction of claims and counterclaims is the main 
guideline to be followed by the politician.

The second part of the answer starts with a question addressed to the interviewer and the audience. What's different. you'll say with Hong Kong? Margaret Thatcher uses the strategy of reformulation, which joins the parts of discourse, making it united and coherent. Here she speaks about Hong Kong as the subject of three agreements made many years ago. According to the last one. Britain had to return Hong Kong to China on the 30th of June 1997. She summarizes the passage with these words:

Only, it 's not barren land. It is a prosperous, thriving commmity: it is Chinese talent, British administration, liberty, justice and rising democracy - has been wonderfil for Chinese people.

Margaret Thatcher manages to demonstrate neutrality in her answer. At first she is emotional but later she maintains neutrality, acting in a composed and more argumentative manner. The use of different linguistic tenses ranging from the Past Indefinite to the Present Indefinite and the Present Prefect puts emphasis on the time and length of the relations between the countries. In the final sentence Margaret Thatcher comments on the current situation in Hong Kong by using words of obvious positive evaluation such as libert: iustice and democracy:

A political interview becomes interesting for the audience if il contains explicitness. Neutrality for a politician leads to the sphere of social truth. However, the concept of a social truth is interpreted differently between politicians of a ruling party and those of an opposition party. While the ruling party's goal is to keep it safe, members of an opposition may integrate other strategies to affect the audience of their speech.

To make the interview sharper, the interviewee challenges Margaret Thatcher:

Shaw: Lady. Thatcher, in the scenario you just painted, you make it sound as if all of this was with Chinas comsent. The fact of the matter is you fought two wars, you cane in and you took Hong Kong.

To achieve his goal, the IR uses several strategies. In formulating the question, he addresses the Prime Minister directly by her surname (Lad) Thatcher). He then expresses his disagreement (in the scenario you just painted, you make it somd as if all of this was with China's consent) and finally initiates an attack on her diplomacy (the matter is you fought two wars, you came in and you took Hong Kong).

Here the IR uses repetition, the most widely used stylistic device in politics. The parallel repetition of the pronoun you intensifies the idea and strengthens its impact on the listener. Her answer is:

We did indeed take two wars, yes. We were, in fact, trating. There was, I'm afiaid, some trade in drugs. None of us would defend that now. We have learnt a great deal in the 100-150 years and I can only wish that Mainland China had so much. If so we would never have had Tiananmen Square. We nould never have had a cultural revolution.

The language behavior of politicians is of social relevance. Hence the choice of linguistic units should be based on the reproduction of the previously known social or cultural knowledge, where memory has its specia! place. We distinguish between short- 
term memory, which deals mainly with interpretation, and long-term memory, which consists of stored knowledge. By using the personal pronoun we and the emphatic construction did take, Margaret Thatcher expresses political unity with the history of Britain. The use of the personal pronoun $w e$ in this context is historically expanded. generalized. The truth expressed in this sentence is objective. Margaret Thatcher does nol want to deviale: she thus uses an emphatic verbal construction and then confirms the truth of her own statement: yes. However, immediately in the following sentence she tries to evade, changing the communicative focus.

We were, in fact, trading. There was, I'm afraid, some trade in dings.

The Prime Minister does not want to focus the attention of the audience on the history of the British Empire. By changing the modality of her tone, she adds to the subjective evaluation of events. The phrase I'm afraid expresses uncertainty. In linguistics, modals of a broader category are called hedges, and they include references to one's own subjective view. Hedges do not only single out the level of uncertainty, but may also be used to show a polite unwillingness to criticize others. So Thatcher passes from the objective reality to the field of subjective evaluation. But as an experienced politician, she has to refer to the sphere of social truth, preserving neutrality in her speech.

The sentence / wish that Mainland China had so much shows that the action expressed by the predicate is presented as something imaginary or desired. She does not say anything about the economic situation in Clina, but by changing the mood, she easily creates an image of a country that is far from desirable. The effect is strengthened in the sentences with unreal condition referring to the past (If so we would never have had Tianammen Square. We would never have had a cultural revolution).

In her answer, Margaret Thatcher proves that language behavior should be of social relevance. She demonstrates the benefits of her foreign policy by revealing the shortcomings of China's policy and hiding the imperial essence of the British Empire.

In this interview the sphere of objective evaluation prevails as an explicit mode over an implicit way of uttering, whereas the sphere of subjective evaluation prevails as an implicit mode over an explicit way of speaking. Throughout the interview, M. Thatcher avoids expressing her own opinion about the leader of China. And when the interviewer asks his question in a very direct way:

Shaw: You don't trust him, do you?

Margaret Thatcher answers: I don't trust a communist, do you?

Thatcher's answer comes off as a rhetorical question, which by its intonation contour and tag presupposes the answer no. There is an implied conceptualization and a notion of warning in her reformulated question. The focus shifts from Deng Xiaoping to the concept of communism. In this case, Margaret Thatcher, without expressing her own opinion about Xiaoping, seeks to preserve neutrality as a kind of manifestation of respect and politeness.

And only once when she is asked:

Shaw: Might things have been better had there been better chemistry between you 
and Deng Xiaoping? During the 1982 talks, referring to you, Mr. Deng said "that woman should be bombarded on of her obstinacy."

Margaret Thatcher: Well, that is what he'd want to say, wouldn't he'? If vou had argued with him you are obstinate. He was obstinate - he argued with ine. But I didn't complain about that. ... Of conse, I um obstinate in defending our liberties and our law: That is whv I cany a big handhag.

Margaret Thatcher's reply might sound less neutral, allowing one to think that it slightly damages her image. However, this aggressive way of answering could lave very well been done on purpose. Thatcher's slightly forceful words implicitly suggest that slie would always defend British policy. This is the reason why she carries a big handbag

Margaret Thatcher was almost always seen with her landbag. Her handbag was regarded as an artifact, as a theatrical entourage and as a symbolic weapon against her political enemies.

The study of non-verbal means of communication reveals that sixty percent of all communication is non-verbal. People seem to use their bodies almost effortlessly, without thinking. In addition, certain elements of a politician's outward aspect and accessories can acquire a symbolic value. Thus, Winston Churchill was seldom seen in public without his cigar. Margaret Thatcher's element of non-verbal communication was her handbag. The latter became such an inseparable part of Thatcher's public image that the verb to handbag has appeared in present-day English in the meaning 'treat ruthlessly or insensitively' (of a woman politician).

In the passage discussed above the Prime Minister is subjective and sincere, yel she still manages to shift the focus to the main trend of governmental policy, referring to symbols of non-verbal comnumication. In her effort to sound objective, Thatcher even ums to well-known values for her defense. For example, when the IR asks:

Shaw: In vour judgment, why does China have such paroxysms over the concept of human rights?

Margaret Thatcher: ...Hunan rights really come from the biblical view In the Old Testament, the 10 Commandments are addressed to each person.... We have the biblical view of the Old Testament that each person matters and the biblical vieu of the New Testament of mercy and redemption.

In the next part, to prove her idea, Margaret Thatcher brings an example from chemistry.

Shaw: Is it conceivable the Hong Kong fever will spread across China's triggering social reform regardless of whether the Chinese leadership wanted them.

Margaret Thatcher: Yes. That is the hope. $I$ is just like putting one little crystal in a big solwion. You know' all of the rest of the solution - in chenistry - crystallizes onto the one crvstal. So ... if you transfer that to China, the kind of administration, the kind of rule of law, the kind of respect for the individual, they too could be a massive Hong Kong. 
Afterwards, to sound objective she refers to history:

Shaw: What is the difference between negotiations, say, with the Russians and the Chinese?

Margaret Thatcher: ... Russia proved what we always said would happen, although it came quicker than we thought. Mr. Gorbachev ... realized the communist sustem wasn't working economically...It doesn't produce prosperity because it offers no stimulus or incentive to people to build up their oun prosperity. China has no history of liberty at all. She has always been ander tyranny.

As an experienced politician Margaret Thatcher has to preserve neutrality in her speech. Thus, she interrupts the IR saying:

Communism will eventually collapse. ... They are born traders, the Chinese. Beijing is so different from what it was in 1977. ... Law is coming to China, initiative is coming to China, enterprise is coming to China. It won't stop.

To relate her own thoughts to the sphere of objective, even universal truth, in this interview Margaret Thatcher refers to history, science and the Bible.

Political interview is an iceberg of information the tip of which should be kept neutral. The rest should be formed by creating the interplay of the objective, subjective and social fields of truth evaluation.

\section{References}

1. Chilton P. Analysing Political Discourse. Theory and Practice. London and New York, Routledge Taylor \& Francis Group, 2004, p.3.

2. Fetzer A. Put bluntly, you have something of a credibility problem. // Politics as Text and Talk. Amsterdam, John Benjamins Publishing Co., 2002, p.188.

3. Crice H.P. Logic and Conversation. // P.Cole and J.L., Morgan (eds.). Syntax and Semantics. New York, Academic Press, 1975, pp. 41-58.

4. Fetzer A. Put bluntly, you have something of a credibility problem. // Politics as Text and Talk. Amsterdam, John Benjamins Publishing Co., 2002, p.182.

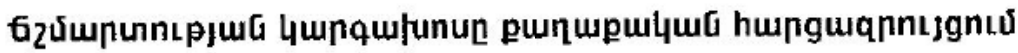

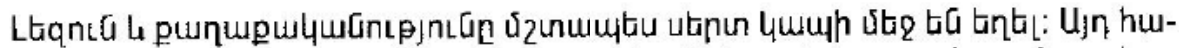

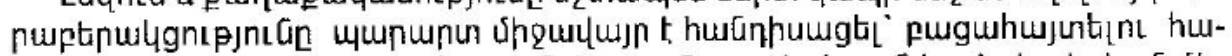

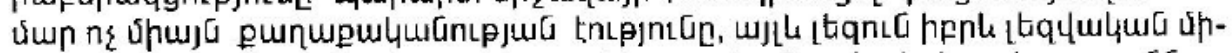

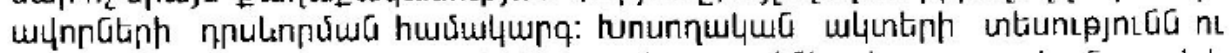

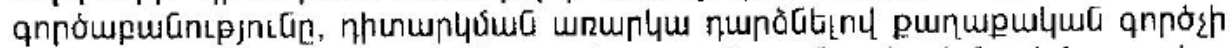

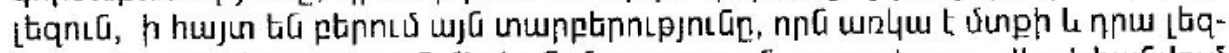

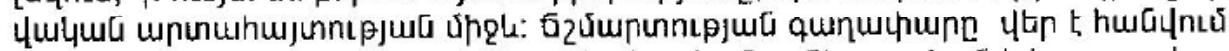

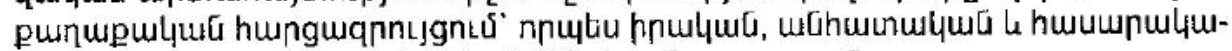

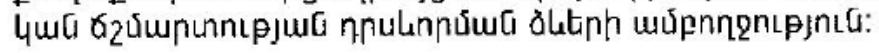

